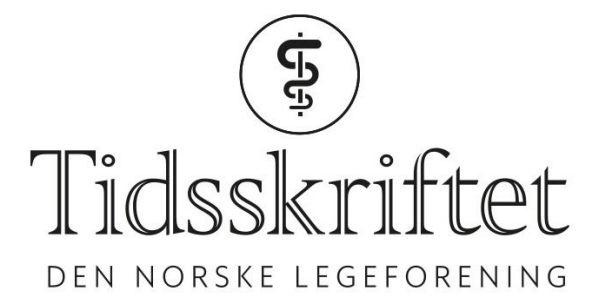

\title{
Norsk pasientskadeerstatning er en god ordning
}

DEBATT

ROLF GUNNAR JØRSTAD

E-post: rgj@npe.no

Rolf Gunnar Jørstad (f. 1958) er cand.jur. og direktør i Norsk pasientskadeerstatning.

Forfatter har fylt ut ICMJE-skjemaet og oppgir ingen interessekonflikter

Dag Bratlid kommer med en rekke påstander vi i Norsk pasientskadeerstatning mener er feil og som vi ønsker å kommentere.

Innledningsvis vil vi bemerke at vi her ikke kan diskutere enkeltsaker, slik Bratlid gjør. Bratlid mener Norsk pasientskadeerstatning (NPE) lar være å gi pasienter erstatning de har krav på. Det er feil. Norsk pasientskadeerstatning har ingen egeninteresse av utfallene i sakene, og vi legger ingen føringer på hvordan de sakkyndige skal konkludere i sine erklæringer.

En del av våre avgjørelser prøves gjennom klagebehandling og i enkelte tilfeller av domstolene. Vi ser på dette som en kvalitetssikring av praksisen vår og legger vekt på å ta lærdom av utfallet av disse sakene.

\section{Sakkyndige må vurdere innen sitt fagfelt}

Norsk pasientskadeerstatning mottar over 6 ooo nye saker i året. I 2016 innhentet vi mer enn 8 ooo sakkyndige vurderinger. For å kunne gi en best mulig medisinsk vurdering av en sak mener vi at det er viktig at den sakkyndige er spesialist innenfor det medisinske fagfeltet saken gjelder. I de fleste saker er det tilstrekkelig med én sakkyndig vurdering for å kunne ta stilling til om pasienten har rett til erstatning. I en del saker trenger vi flere sakkyndige vurderinger for å vurdere ulike deler av forløpet.

Et eksempel på det siste er at en spesialist innenfor anestesiologi vurderer anestesibehandlingen, mens en spesialist i kirurgi vurderer den kirurgiske behandlingen. Fordi hvert fagfelt er spesialisert, er det viktig at den sakkyndige har spesialkompetanse på det han eller hun vurderer. Vi er ikke enig med Bratlid $i$ at de fleste leger i stor grad kan vurdere om god medisinsk praksis er fulgt, også innen andre spesialiteter enn deres egen.

Når han hevder at en kirurg kan vurdere om fastlegen har utredet pasienten godt nok og henvist tidsnok, mener vi at en allmennmedisiner er nærmere til å gi en god faglig vurdering. Vi mener det er allmennmedisineren som best kjenner normene og retningslinjene innen allmennmedisin og er i stand til å vurdere hva som er relevant og riktig for fastlegen å gjøre i det enkelte tilfellet, ikke kirurgen som har sin arbeidsdag på et sykehus. Lang erfaring som lege gjør ikke en sakkyndig mer kompetent til å vurdere forhold 
utenfor eget fagfelt. Dette mener vi Bratlid, som alle andre sakkyndige, må forholde seg til.

At de sakkyndige skal vurdere spørsmål innenfor eget fagfelt, innebærer ikke at de ikke kan peke på det de tror kan være svikt på andre områder av behandlingen enn den de selv er bedt om å vurdere. Vi oppfordrer de sakkyndige til å gjøre oss oppmerksom på andre forhold som kan være av betydning for saken. Finner vi at relevante forhold blir påpekt, vil vi be en spesialist på det aktuelle området om å vurdere nettopp det. Likevel skjer dette sjelden, sakkyndige er generelt varsomme med å påpeke forhold utenfor eget spesialområde. Svært mye av det som skjer innenfor et medisinsk fagfelt i dag er så spesialisert at sakkyndige uten den relevante spesialiteten ofte ikke vil anse seg kompetente til å komme med slike vurderinger.

\section{Ikke avslag på ufullstendig grunnlag}

Bratlid mener at pasienten har krav på at alle avvik fra god medisinsk praksis skal med i erklæringen. Norsk pasientskadeerstatnings hovedoppgave er å vurdere om erstatningssøkere har rett til erstatning eller ikke.

Vi vurderer erstatningskrav fra pasienter, ikke «klager på feilbehandling», som Bratlid beskriver det. Da må vi vurdere forhold som er relevante for erstatningssaken, ikke nødvendigvis andre avvik.

\section{Pasientskadeordningen innebærer lovanvendelse}

Norsk pasientskadeerstatning er satt til å forvalte et lovverk. Det krever juridisk kompetanse. Det virker ikke som om Bratlid helt forstår at vi må gjøre juridiske vurderinger i hver enkelt sak for å kunne fatte et vedtak.

Det er et vilkår i pasientskadeloven at et krav ikke må være foreldet, at det må være svikt i behandlingen som har ført til en skade og at det er et økonomisk tap. Tilfredsstiller ikke en sak alle disse vilkårene, har ikke erstatningss $\varnothing$ keren rett til erstatning. Begrepet svikt i ytelsen av helsehjelp (pasientskadeloven § 2, første ledd bokstav a) er en rettslig standard der de sakkyndige vurderingene utgjør sentrale premisser for lovanvendelsen.

\section{Det medisinske er viktig}

Samtidig er det åpenbart at det medisinske også vil stå sentralt i en virksomhet som Norsk pasientskadeerstatning. Vi kjenner oss ikke igjen i Bratlids beskrivelse av at vi ikke vektlegger medisinsk kompetanse i organisasjonen.

Vi har én heltidsansatt lege som leder for de sakkyndige tjenestene. Vi innhenter over 8 ooo sakkyndige vurderinger i året og har avtaler med over go sakkyndige spesialister i 30 kliniske spesialiteter. I tillegg benytter vi flere hundre sakkyndige fra hele landet til enkeltoppdrag.

Vi har god dialog med dem som utfører oppdrag for oss. På denne måten kan vi hele tiden sikre at vi får gode sakkyndige uttalelser og kan justere rutiner, praksis og gjennomføring av medisinsk sakkyndigvurdering i sakene.

At Bratlid opplever ikke å få gjennomslag for sine ideer om det han mener er en god sakkyndig utredning, handler ikke om at vi ikke tar kritikken alvorlig, men at vi er uenig med ham.

Vi er opptatt av verdien av de sakkyndige uttalelsene i vårt oppdrag med å gi så vel helsetjenesten som helsemyndighetene skadestatistikk og oversikt over skader, skadeomfang og risiko. Bare det siste året er det publisert flere artikler (1-4) som bygger på dette materialet eller som viser til betydningen av at det benyttes. Materialets verdi er selvsagt avhengig av at sakene er vurdert av kompetente og relevante sakkyndige.

Norsk pasientskadeerstatning har de siste tre årene tilkjent erstatning til 4301 pasienter og pårørende og utbetalt tre milliarder kroner i erstatninger. Vi mener vi har 
en god og viktig erstatningsordning i Norge.

\section{LITTERATUR:}

1. Kongsgaard UE, Fischer K, Pedersen TE et al. Klager etter nerveblokade til Norsk pasientskadeerstatning 2001-14. Tidsskr Nor Legeforen 2016; 136:1989 - 92. [PubMed][CrossRef]

2. Alfsen GC, Chen Y, Kähler H et al. Patologirelaterte saker i pasientskadeordningen i perioden 2010-15. Tidsskr Nor Legeforen 2016; 136:1984- 7. [PubMed][CrossRef]

3. Ræder J. Hva kan vi lære når staten betaler for våre feil? Tidsskr Nor Legeforen 2016; 136:1956. [PubMed][CrossRef]

4. Fornebo I, Simonsen KA, Bukholm IRK et al. Claims for compensation after injuries related to airway management: a nationwide study covering 15 years. Acta Anaesthesiol Scand 2017; 61: 781 - 9. [PubMed][CrossRef]

Publisert: 12. desember 2017. Tidsskr Nor Legeforen. DOI:10.4045/tidsskr.17.0997

Mottatt 14.11.2017, godkjent 22.11.2017.

(C) Tidsskrift for Den norske legeforening 2020. Lastet ned fra tidsskriftet.no 